\title{
CHARACTERIZATION OF SILICON NITRIDE LAYERS DEPOSITED IN THREE-ELECTRODE PLASMA-ENHANCED CVD CHAMBER
}

\author{
T. Grigaitis a , A. Naujokaitis ${ }^{\text {a }}$, S. Tumènas ${ }^{\text {b }}$, G. Juška ${ }^{\text {a }}$, and K. Arlauskas ${ }^{\text {a }}$ \\ ${ }^{a}$ Department of Solid State Electronics, Vilnius University, Sauletekio 9, LT-10222 Vilnius, Lithuania \\ ${ }^{\mathrm{b}}$ Department of Optoelectronics, Center for Physical Sciences and Technology, A. Goštauto 11, LT-01108 Vilnius, Lithuania \\ E-mail: tomasgrigaitis@gmail.com
}

Received 16 December 2014; revised 1 February 2015; accepted 20 March 2015

\begin{abstract}
Two series of amorphous silicon nitride films were deposited using a chemical vapour deposition (CVD) reactor with two and three electrodes. Nitrogen gas and silane diluted with argon mixture $\left(5 \% \mathrm{SiH}_{4}+95 \% \mathrm{Ar}\right)$ were used as the working gas. The silicon nitride films were deposited at the same time on $\mathrm{CaF}_{2}$ and aluminium-coated glass substrates at $300{ }^{\circ} \mathrm{C}$. Changing of the injected gas ratios allowed us to shift the band gap of the films in the $1.85-5.15 \mathrm{eV}$ range. From AFM analysis it was found that the samples deposited in a three-electrode chamber demonstrated lower surface roughness. The electrical measurements revealed that the samples deposited in the three-electrode CVD reactor demonstrated lower leakage current and higher breakdown voltage. The composition of layers was investigated using energy-dispersive X-ray (EDS) and Fourier transform infrared (FTIR) spectroscopies. Additionally, the composition of the deposited films was evaluated from the refractive indexes, which have been estimated by fitting the spectroscopic ellipsometry data using the Tauc-Lorenz model.
\end{abstract}

Keywords: silicon nitride, plasma deposition, CVD, EDS, FTIR

PACS: 61.43.Er, 81.15.Gh, 85.40.Sz

\section{Introduction}

Silicon nitride $\left(\mathrm{SiN}_{x}\right)$ films have been widely investigated due to their exceptional properties. The $\mathrm{SiN}_{x}$ material is used as an effective antireflective coating and surface passivation layer in crystalline silicon solar cells [1-2] and a diffusion barrier in the integrated circuit technology. It is also used for visible light emitting devices [3]. In addition to its perfect electrical properties, silicon nitride shows high thermal stability and mechanical strength. Refractive index, optical band gap and molecular composition of the film can be tuned depending on deposition conditions [ [4]. The ability to change composition of the film is required for the formation of controlled band gap nanodevices. Multilayer structures of $\mathrm{Si} / \mathrm{SiN}_{x}[5]$ and $\mathrm{SiN}_{x} / \mathrm{SiN}_{y}$ [6] are promising as silicon-based light-emitting structures. Therefore the ability to deposit uniform layers and alter the band gap in a wide range is one of the most urgent tasks of the silicon nitride technology.

$\mathrm{SiN}_{x}$ can be prepared by a number of methods including plasma enhanced chemical vapour deposition (PECVD), hot wire chemical vapour deposition (HWCVD) and direct current or radio frequency magnetron sputtering. The conventional parallel plate PECVD reactors are widely used in modern micro- electronic industry. However, they have some limitations. Samples are placed on one of its two electrodes which results in energetic bombardment of the film by charged particles. The latter cause surface damage and high film stress. The damage by plasma particles using this method is a problem for compound semiconductor devices such as GaAs IC or light-emitting devices [⿰申]. Moreover, for $\mathrm{SiN}_{x}$ deposition $\mathrm{SiH}_{4}$ mixture with $\mathrm{NH}_{3}$ or $\mathrm{N}_{2}$ gases is used. Due to higher dissociation energy of $\mathrm{N}_{2}$ or $\mathrm{NH}_{3}$ compared to $\mathrm{SiH}_{4}$, it is complicated to incorporate a high amount of $\mathrm{N}$ atoms into a deposited layer [8]. The deficiency of nitrogen in the film could be solved using the HWCVD technique. This deposition method allows depositing the $\mathrm{SiN}_{x}$ films with a high nitrogen and a low hydrogen concentration. One of the weaknesses of the HWCVD technique is the reaction of a filament with silane gas. This leads to a degradation of the filament.

In this work, an effective approach based on plasma separation by a net electrode has been proposed for deposition of the $\mathrm{SiN}_{x}$ films with a high nitrogen concentration and a uniform surface. It should be noted that nitrogen gas has been used as an $\mathrm{N}$ source. In comparison with ammonia gas, nitrogen gas is environment-friendly and less expensive to produce, but the dissociation into nitrogen atoms is more difficult. 
The use of nitrogen gas as a source of nitrogen atoms in our three-electrode CVD device allowed us to grow the $\mathrm{SiN}_{x}$ layers, whose energy gap could be changed in a wide range of energies. We have studied the optical, morphological, compositional and electrical properties of these layers, which were compared with the properties of the $\mathrm{SiN}_{x}$ layers grown in the two-electrode CVD equipment because the data about deposition of the $\mathrm{SiN}_{x}$ layers in a three-electrode chamber by other authors are absent.

\section{Experiment}

In the same two- and three-electrode deposition CVD chambers two series of samples were produced simultaneously yielding layers on both $\mathrm{CaF}_{2}$ and on Al-coated glass substrates. The first series of samples $\left(\mathrm{SiN}_{x}-\mathrm{III}\right)$ were produced using the method of RF PECVD chamber with three horizontal stainless steel electrodes (Fig. 1). $\mathrm{N}_{2}$ gas was injected with a gas flow rate up to 10 standard cubic centimetres per minute $(\mathrm{sccm})$ through a grounded showerhead electrode (D), which ensured a uniform flow of gas. Due to high nitrogen and silane gas dissociation energy difference, the silane and argon gas mixture $\mathrm{SiH}_{4}(5 \%)+\mathrm{Ar}(95 \%)$ entered the field of plasma through a side nozzle in the reactor. The plasma was excited between the shower (D) and the grid (T) electrode using the constant power of a $23 \mathrm{MHz}$ frequency generator $(\mathrm{G})$. The negative DC voltage was applied to the sample holder $(S)$ because in the case of the grounded sample holder, the plasma region spreads

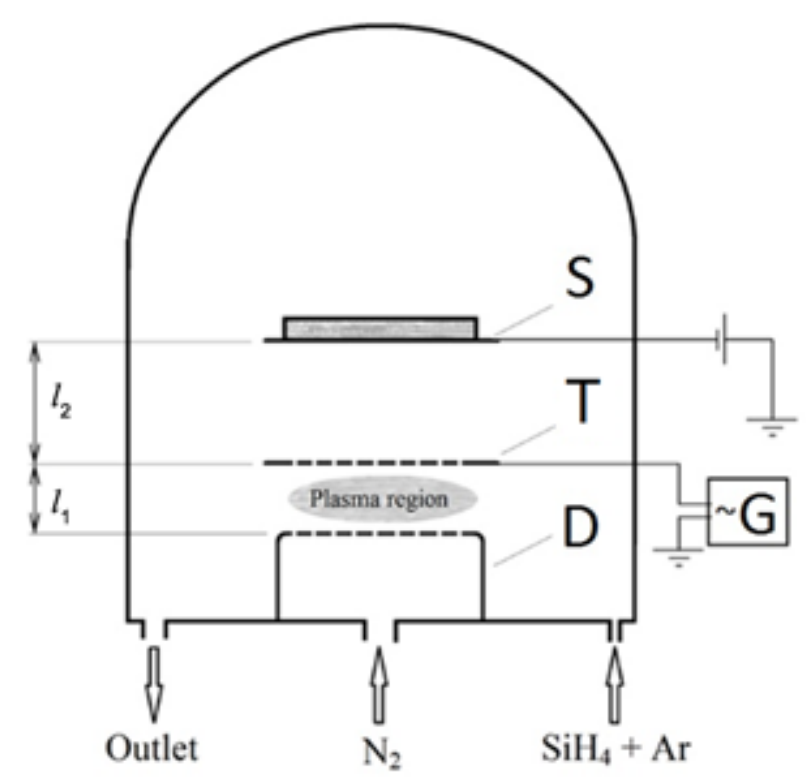

Fig. 1. Schematic view of the deposition system. Details are in the text. into the deposition chamber and gets in contact with the growing surface of $\mathrm{SiN}_{x}$. The deposition growth rate of the film linearly increased with the increase of the negative voltage of the sample holder, but it also increases the possibility of electrical breakdown in the deposition chamber (Fig. 2). After several attempts it was found that $-30 \mathrm{~V}$ is optimal at which electric breakdown does not occur. The distance from the electrode $\mathrm{T}$ to the shower shape electrode was $3.5 \mathrm{~cm}\left(l_{1}\right)$ and $7 \mathrm{~cm}$ was the distance $\left(l_{2}\right)$ to the sample holder. The second series of samples $\left(\mathrm{SiN}_{x}-\mathrm{I}\right)$ were deposited in the CVD chamber without the net electrode $\mathrm{T}$. In this case, the power generator has been connected to the S and D electrodes as in the conventional parallel-plate CVD reactor. The distance between the electrodes was $3.5 \mathrm{~cm}$. It should be noted that this distance is three times smaller than that in the previous method. For the deposition of all the layers the temperature of substrate and the pressure of gas mixture in the chamber was $300^{\circ} \mathrm{C}$ and 0.2 Torr,

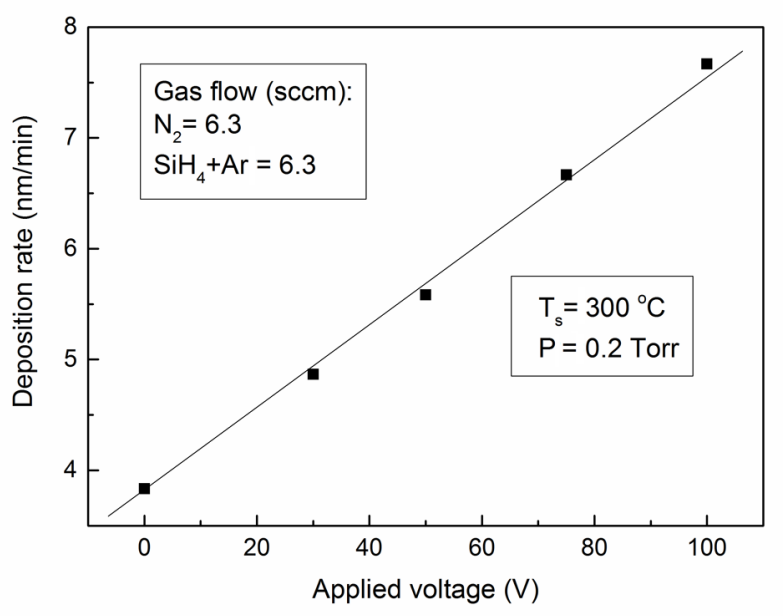

Fig. 2. Deposition rate as a function of voltage applied onto a sample holder.

respectively. The thickness of the $\mathrm{SiN}_{x}$ films varied from $556 \mathrm{~nm}$ to $606 \mathrm{~nm}$. The gas flows and deposition rates are shown in Table 1 .

For electrical measurements the $1 \mathrm{~mm}$ in diameter $\mathrm{Al}$ electrodes were vacuum evaporated on the top of the $\mathrm{SiN}_{x}$ films. In order to evaluate stoichiometry of the films the energy-dispersive X-ray spectrum (EDS) was measured at $4 \mathrm{kV}$ electron acceleration voltage. Using a Lambda 1050 UV-Vis spectrophotometer (PerkinElmer Inc.) optical absorbance of the $\mathrm{SiN}_{x}$ films was investigated. The surface of the films was tested using atomic force microscopy (AFM). The electrical properties of the films were measured and analysed. Bond structures and composition of the $\mathrm{SiN}_{x}$-III films were 
Table 1. Deposition parameters and properties of $\mathrm{SiN}_{x}$ layers.

\begin{tabular}{c|c|c|c|c|c|c|c}
\hline $\begin{array}{c}\text { Series of } \\
\text { sample }\end{array}$ & $\begin{array}{c}\text { Deposition rate, } \\
\mathrm{nm} / \mathrm{min}\end{array}$ & $\mathrm{N}_{2}, \mathrm{sc} \mathrm{cm}$ & $\begin{array}{c}\mathrm{SiH}_{4}+\mathrm{Ar}, \\
\mathrm{sc} \mathrm{cm}\end{array}$ & Ratio $R$ & $E_{\mathrm{g}}, \mathrm{eV}$ & $\begin{array}{c}\text { Thickness, } \\
\mathrm{nm}\end{array}$ & $\begin{array}{c}\mathrm{N} / \mathrm{Si} \\
(\mathrm{EDS})\end{array}$ \\
\hline III & 10.1 & 0 & 6.3 & 0 & 1.85 & 606 & - \\
\hline III & 4.63 & 6.3 & 12.6 & 0.5 & 2.32 & 556 & 0.69 \\
\hline III & 4.86 & 6.3 & 10 & 0.63 & 3.8 & 585 & 0.98 \\
\hline III & 4.95 & 6.3 & 6.3 & 1 & 4.4 & 594 & 1.35 \\
\hline III & 4.85 & 10 & 6.3 & 1.59 & 5.15 & 582 & 1.44 \\
\hline II & 8.14 & 6.3 & 6.3 & 1 & 2.35 & 570 & 0.62 \\
\hline II & 8.35 & 12.6 & 6.3 & 2 & 2.85 & 585 & 0.76 \\
\hline II & 8.12 & 31.5 & 6.3 & 5 & 3.5 & 569 & 1.01 \\
\hline II & 8.28 & 63 & 6.3 & 10 & 3.9 & 580 & 1.21 \\
\hline
\end{tabular}

investigated in more detail using Fourier transform infrared spectroscopy (FTIR). Also, spectroscopic ellipsometry (SE) measurements were performed using a dual rotating compensator ellipsometer RC2 (J.A. Woollam Co, Inc.) at the incidence angles of 45, 55 and 65 deg in the 200-1700 $\mathrm{nm}$ wavelength range.

\section{Results and discussion}

\subsection{EDS measurements}

Elemental composition of the films was determined using EDS measurements. Due to deep penetration of the electron beam into the layer, EDS measurements are not so attractive for the thin film characterization. For X-ray generation the energy of electron beam must be at least twice bigger than the highest energy of excited X-ray radiation. In the case of $\mathrm{SiN}_{x}$, the highest intensity of $\mathrm{X}$-ray radiation is emitted as a $\mathrm{K}_{\alpha}$ photon of $\mathrm{Si}$ at approximately $1.78 \mathrm{keV}$. For the EDS measurements and according to the Monte Carlo simulation using CASINO v2.42 software [9], the $4 \mathrm{kV}$ acceleration voltage was selected.

The EDS spectrum allowed us to estimate the N/ $\mathrm{Si}(\mathrm{N} / \mathrm{Si}=x)$ atomic ratio of the samples (Table 1). An additional electrode in the CVD chamber allowed us to incorporate a high amount of nitrogen $(x=1.44)$ into the $\mathrm{SiN}_{x}$ films at a low gas volume ratio of $\mathrm{N}_{2} / \mathrm{SiH}_{4}(R=1.59)$. Influence of the additional electrode in the deposition chamber can be clearly seen by comparing the samples deposited with the same gas flow ratio $(R=1)$, but with different electrode configuration. The three electrode CVD chamber allows to deposit the $\mathrm{SiN}_{x}$ layers with higher concentration of nitrogen $(x=1.35)$ at the same gas flow. In the latter case, the silane and argon gas mixture has no direct contact with the plasma, leading to the formation of a limited quantity of silane moieties which during the growth of the layer can act as the precursors.
The EDS spectrum revealed absence of $\mathrm{Al}$ in the $\mathrm{SiN}_{x}$ layers, although the films were deposited on aluminium-coated substrates. The latter result allowed us to state that the thicknesses of the $\mathrm{SiN}_{x}$ films were sufficient so that the electron beam was fully absorbed and electrons did not reach the substrate. These measurements confirmed the numerical modelling results. All the deposited $\mathrm{SiN}_{x}$ films contain a small amount of oxygen $(2-4 \%)$ and carbon $(1-2 \%)$.

\subsection{Optical measurements}

The UV-visible absorption spectra of the films deposited on $\mathrm{CaF}_{2}$ substrates were measured. The optical energy band gap value of the film can be obtained from absorption measurements using the well known Tauc's formula [10]:

$$
(\alpha h v)^{1 / 2}=B\left(h v-E_{\mathrm{g}}\right),
$$

where $\alpha$ is the absorption coefficient, $B$ is the constant, $h v$ is the photon energy and $E_{\mathrm{g}}$ is an optical band gap. In Fig. 3 the Tauc's plots of the deposited $\mathrm{SiN}_{x}$ samples are shown. Linear extrapolation of the curve allows to set $E_{\mathrm{g}}$ because the Tauc's model considers only direct optical transitions. The oscillation observed in the spectrum is determined by the interference fringes in the film. Using a three-electrode CVD chamber it was possible to change the width of the energy gap from $1.85 \mathrm{eV}$ (amorphous silicon) to $5.15 \mathrm{eV}(R=1.59)$ with increasing the gas ratios $R$ (Table 1). The latter electrode configuration was much more sensitive to gas ratio variation than in the case of parallel-plate configuration. Moreover, using the parallel-plate configuration the widest band gap of the samples was only $3.9 \mathrm{eV}$ at $R=10$. As expected, the band gap of silicon nitride increased with increasing nitrogen content in the films for both series of the samples. 

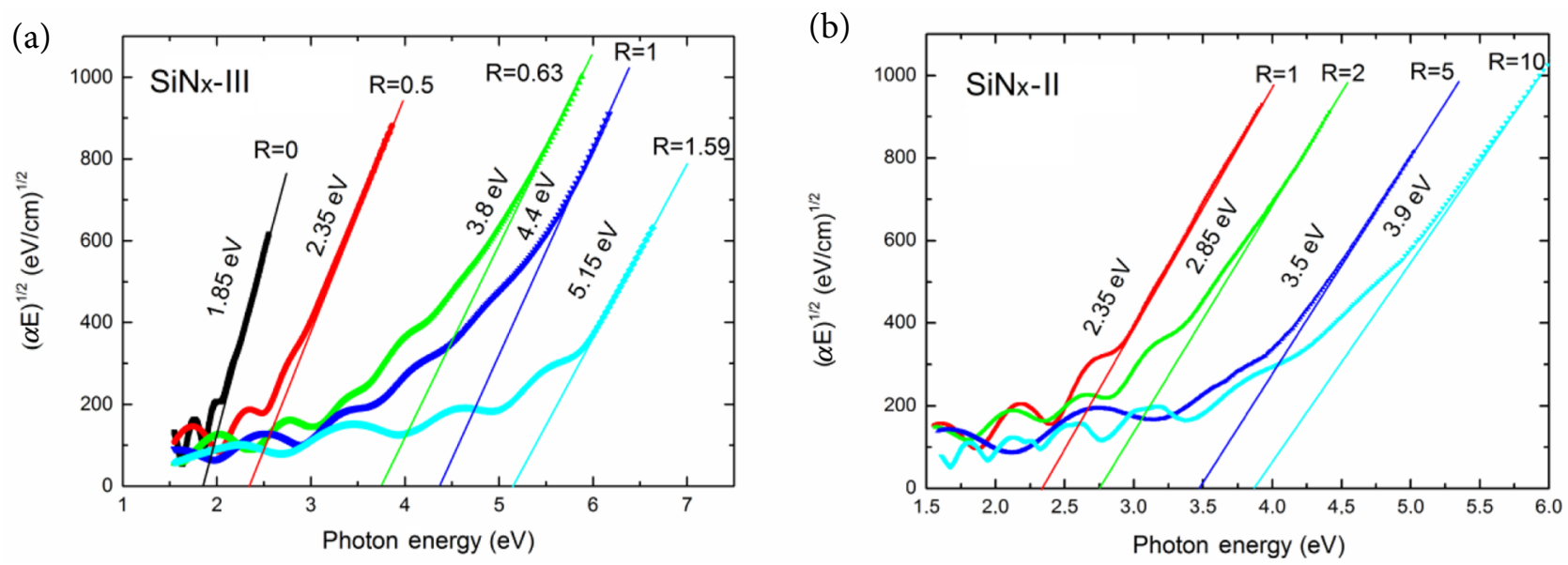

Fig. 3. Absorption dependencies (Tauc's plot) of silicon nitride samples deposited in (a) three-electrode and (b) twoelectrode CVD chamber.

\subsection{Surface roughness}

Surface roughness of the $\mathrm{SiN}_{x}$ samples, prepared using different configurations of the chamber, was examined usingAFM. Thestoichiometriclayers $\left(x=1.35 \mathrm{ofSiN}_{x}-\mathrm{III}\right.$ and $x=1.21$ of $\mathrm{SiN}_{x}$-II) that have been deposited on aluminium-coated glass substrates were chosen for comparison. Figure 4 shows the surface morphology of the films. It is clearly seen that the surface of the $\mathrm{SiN}_{x}-\mathrm{II}$ film consists of higher density and larger nanometre-size grains than ones of the $\mathrm{SiN}_{x}$-III sample. The measured root-mean-square roughness of the area was $9.4 \mathrm{~nm}$ and $3.9 \mathrm{~nm}$ for the $\mathrm{SiN}_{x}-\mathrm{II}$ and $\mathrm{SiN}_{x}-$ III films, respectively. This difference could be due to different configuration of the electrodes in the chamber. In a parallel-plate reactor the surface of the layers is bombarded by the charged particles, which may lead to a rougher surface of the layer. On the other hand, this difference in roughness may also be influenced by different deposition rates because the parallel-plate CVD configuration causes accelerated film growth, which can lead to higher surface roughness.

\subsection{Breakdown strength and leakage current}

For application purposes a critical parameter of the dielectric layer is a magnitude of breakdown electrical field. Although the breakdown voltage is an intrinsic property of the material, however, the maximal breakdown magnitude may vary depending on the surface roughness, imperfections as well as on the thickness of the film. Even the area of the electrode has influence on the magnitude of breakdown voltage [9].

The samples, which have been tested using AFM, were chosen for electrical measurements. The measurements of current-voltage $(I-V)$ characteristics were made for the both polarities of voltage on the electrodes, however, the $I-V$ dependences were identical.

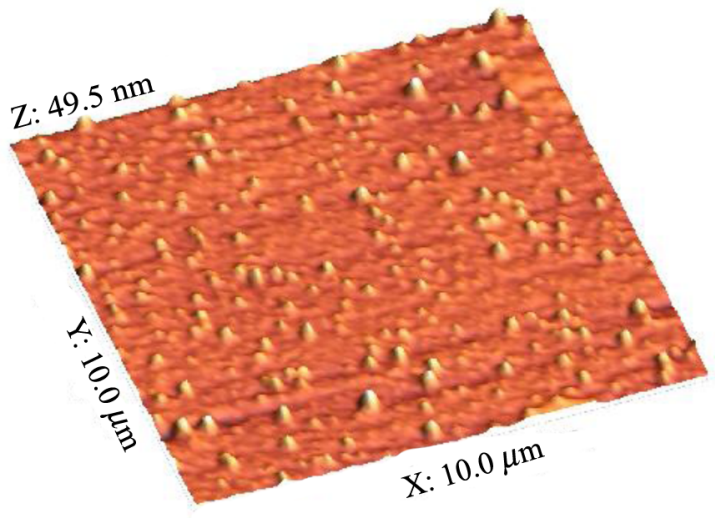

(a)

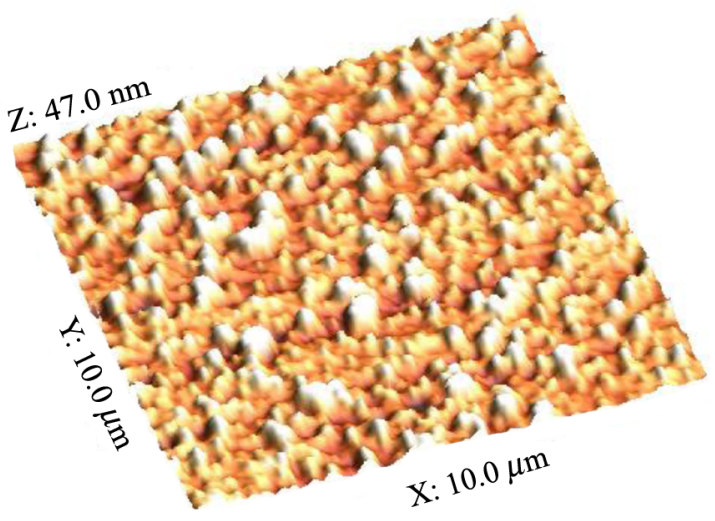

(b)

Fig. 4. AFM surface images of (a) $\operatorname{SiN}_{x}-\mathrm{III}(x=1.35)$ and (b) $\operatorname{SiN}_{x}-\mathrm{II}(x=1.21)$ samples. 
In Fig. 5 the current density dependences on the electric field of the samples deposited in the two- and three-electrode systems are compared.

The current density dependence at high electrical field can be interpreted as the Poole-Frenkel (PF) emission [12]. The PF emission occurs due to the field-enhanced thermal emission of trapped electrons to the conduction band, and the current density is described by a general expression

$$
J=A E \exp \left[-\frac{q \Phi_{\mathrm{B}}-\beta \sqrt{E}}{\xi k T}\right],
$$

where $\beta=\sqrt{q^{3} / \pi \varepsilon \varepsilon_{0}}, A$ is the constant, $\Phi_{\mathrm{B}}$ is the barrier height, $\varepsilon$ is the dielectric permittivity, $k$ is the Boltzman constant, and $\xi$ is the correction factor which may vary between one and two, depending on the amount of the compensating acceptor. The PF plot of $\ln (J / E)$ versus $\sqrt{E}$ yields a straight line:

$$
\ln \left(\frac{J}{E}\right)=\frac{\beta \sqrt{E}}{\xi k T}+\left(\ln A-\frac{q \Phi_{\mathrm{B}}}{\xi k T}\right) .
$$

The typical linear part of the PF plot is shown as an insert in Fig. 5 and is taken as the evidence of PF conduction. The slope of the PF plot is proportional to $\beta$ and can be expressed by

$$
S=\frac{\beta}{\xi k T} \text {. }
$$

The experimentally measured slopes for the $\mathrm{SiN}_{x}-$ II and $\mathrm{SiN}_{x}$-III samples are 0.0129 and 0.0121 , respectively. The theoretical value of the slope $S$ for stoichiometric $\mathrm{Si}_{3} \mathrm{~N}_{4}(\varepsilon=7)$ is 0.0111 , which is fairly close to the measured values. If we assume that $\xi=1$, then $\varepsilon=5.2$ and 5.9 for the $\mathrm{SiN}_{x}-\mathrm{II}$ and $\mathrm{SiN}_{x}$-III samples, respectively. The discrepancy may occur since $\xi$ is not strictly equal to one and depends on the nature and density of traps in the film. For the determination of $\varepsilon$ we consider that electrical field in the film is homogeneous, however, it is known that the charge carriers injected into the $\mathrm{SiN}_{x}$ film are trapped and create a space charge. The dielectric constant in the visible range $(\sim 500 \mathrm{~nm})$ is $\sim 4$ and the static dielectric constant is around 7 , therefore, the dynamic dielectric constant must range between 4 and 7 [13].

The $\mathrm{SiN}_{x}$ samples deposited using the three-electrode CVD reactor, at the same electric field, demonstrated lower current density compared to that of the samples prepared using the two-electrode configuration CVD reactor. Since most of field-effect devices operate at approximately $2 \mathrm{MV} / \mathrm{cm}$ electrical field [14], it is reasonable to compare current density particularly at this electrical field strength. At $2 \mathrm{MV} / \mathrm{cm}$, the average current density is $3.6 \times 10^{-9} \mathrm{~A} / \mathrm{cm}^{2}$ and $7.9 \times 10^{-8} \mathrm{~A} / \mathrm{cm}^{2}$ for the $\mathrm{SiN}_{x}$-III and the $\mathrm{SiN}_{x}$-II films, respectively. The measurements on different electrodes of the same sample did not show any significant fluctuation of current magnitude while the breakdown strength ranges from $4.6 \mathrm{MV} / \mathrm{cm}$ to $5.3 \mathrm{MV} / \mathrm{cm}$ for the $\mathrm{SiN}_{x}-\mathrm{III}$ and from $3.4 \mathrm{MV} / \mathrm{cm}$ to $3.9 \mathrm{MV} / \mathrm{cm}$ for the $\mathrm{SiN}_{x}$-II films. In our case, taking into account the AFM measurements, lower breakdown strength of the $\mathrm{SiN}_{x}$-II film can be explained by higher surface roughness and not necessarily by the intrinsic properties of material. In the region of weak electrical fields the current density dependence on the electric field corresponds to the Ohm's law [11]. In a weak electric field $(0.5 \mathrm{MV} / \mathrm{cm})$, the average estimated resistances of the

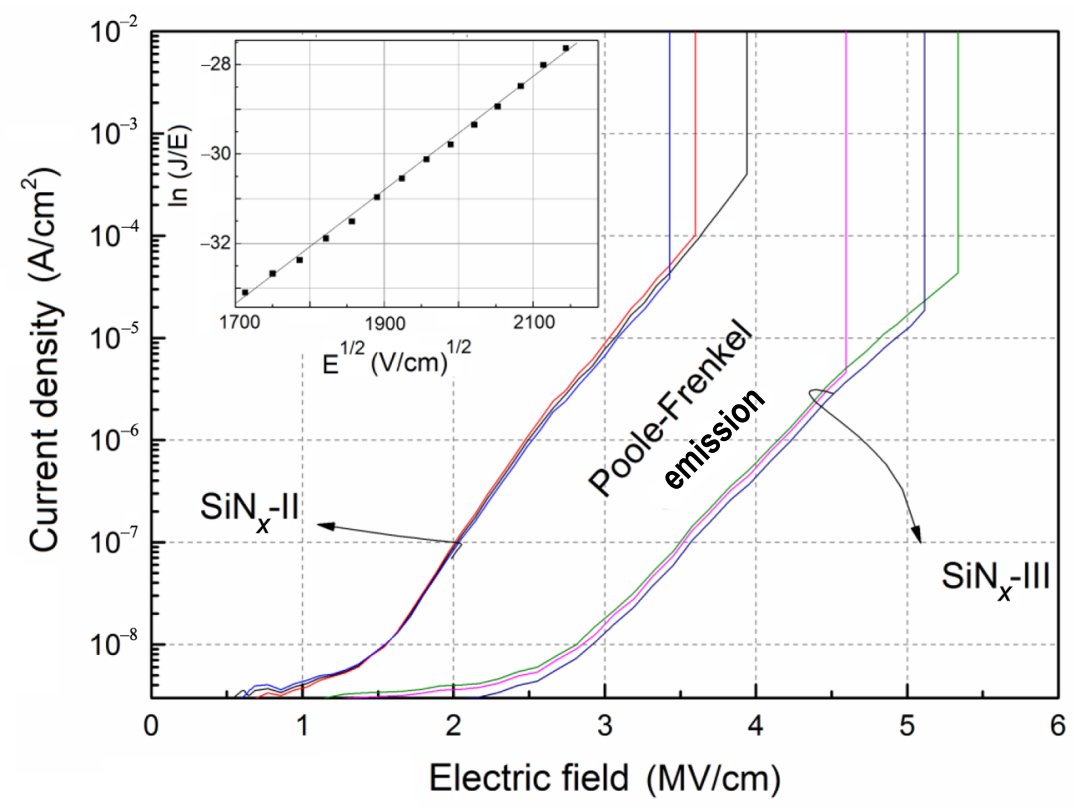

Fig. 5. Dependences of current density on electric field of $\mathrm{SiN}_{x}$-II $(x=1.21)$ and $\operatorname{SiN}_{x}$-III $(x=1.35)$ samples. The insert shows a typical linear part of PF plot. 
$\mathrm{SiN}_{x}$-III and $\mathrm{SiN}_{x}$-II films are $5.47 \times 10^{14} \Omega \mathrm{cm}$ and $2.4 \times 10^{14} \Omega \mathrm{cm}$, respectively. Although the electrical properties of PE CVD silicon nitride depends on the method of deposition, the both samples demonstrate a decent resistivity value of $>10^{13} \Omega \mathrm{cm}[11,15]$.

\subsection{FTIR measurements}

The structure of the bonds of $\mathrm{SiN}_{x}-\mathrm{III}$ material was examined using the FTIR method. The FTIR measurements were performed in the specular reflection from the $\mathrm{SiN}_{x}$ samples deposited on aluminium-coated glass substrates, thus, for estimation of density of the bonds double thickness of the layer has been used. As the layer thickness is less than half of the irradiation wavelength, possible changes of the positions of absorption bands may be expected [16].

Figure 6 shows the FTIR spectra of the $\mathrm{SiN}_{x}$-III samples deposited at different gas ratios. Interference effects in the films were removed from the spectra via the base line correction technique, and the spectra were normalized to the $\sim 2185 \mathrm{~cm}^{-1}$ absorption band. The peak at $\sim 860 \mathrm{~cm}^{-1}$ is assigned to the vibrations of $\mathrm{Si}-\mathrm{N}$ asymmetric stretching [17]. The shoulder at $\sim 1180 \mathrm{~cm}^{-1}$ and the vibration band at $\sim 3345 \mathrm{~cm}^{-1}$ are attributed to the $\mathrm{N}-\mathrm{H}$ rocking and stretching modes, respectively [17, 18]. The peak at $2185 \mathrm{~cm}^{-1}$ is assigned to the $\mathrm{Si}-\mathrm{H}$ stretching band [17]. This absorption band demonstrates the blue shift with increasing gas ratio. The samples, deposited at higher gas ratios, also exhibit a small peak at $1545 \mathrm{~cm}^{-1}$, which can be assigned to the $\mathrm{NH}_{2}$ bending vibration [19]. The IR absorption areas of $\mathrm{Si}-\mathrm{H}$ and $\mathrm{N}-\mathrm{H}$ bonds were integrated and multiplied by the constants determined by Lanford et al. [20]. This allowed us to evaluate the density of $\mathrm{Si}-\mathrm{H}$ and $\mathrm{N}-\mathrm{H}$ bonds (Table 2). The stoichiometry of the film was obtained from the following expression [21]:

$$
\frac{1}{x}=\frac{\mathrm{Si}}{\mathrm{N}}=0.084 \frac{[\mathrm{Si}-\mathrm{H}]}{[\mathrm{N}-\mathrm{H}]}+0.70 .
$$

Table 2. SE and FTIR results of $\mathrm{SiN}_{x}$-III series of samples.

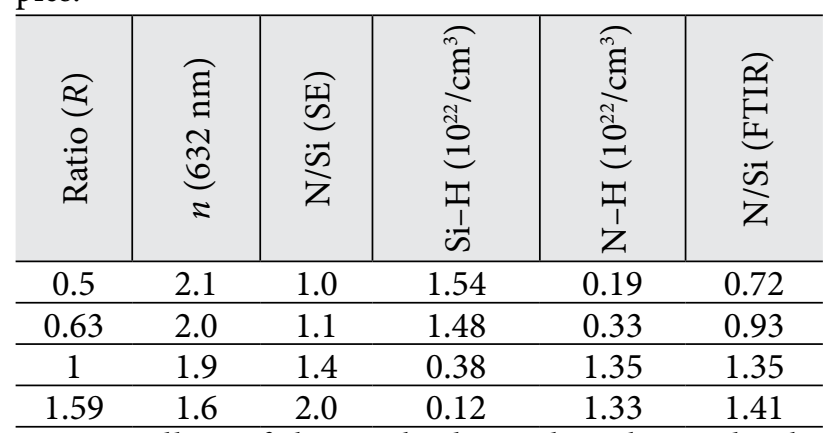

Regardless of the methods used in the study, the evaluated $\mathrm{Si} / \mathrm{N}$ ratio increased with the value of $R$, however, slight changes of the final values of the $\mathrm{Si} / \mathrm{N}$ ratio were observed (Table 2).

\subsection{Ellipsometric measurements}

Experimental SE data in terms of the ellipsometric parameters $\Delta$ and $\Psi$ for the $\mathrm{SiN}_{x}$-III sample are presented by dots in Fig. 7. The clearly pronounced oscillations are due to interference from the $\mathrm{SiN}_{x}$ layer. The oscillations fade out in the short-wavelength region above the absorption onset of $\mathrm{SiN}_{x}$. The refractive index of $\mathrm{SiN}_{x}$ was determined from the experimental SE data using

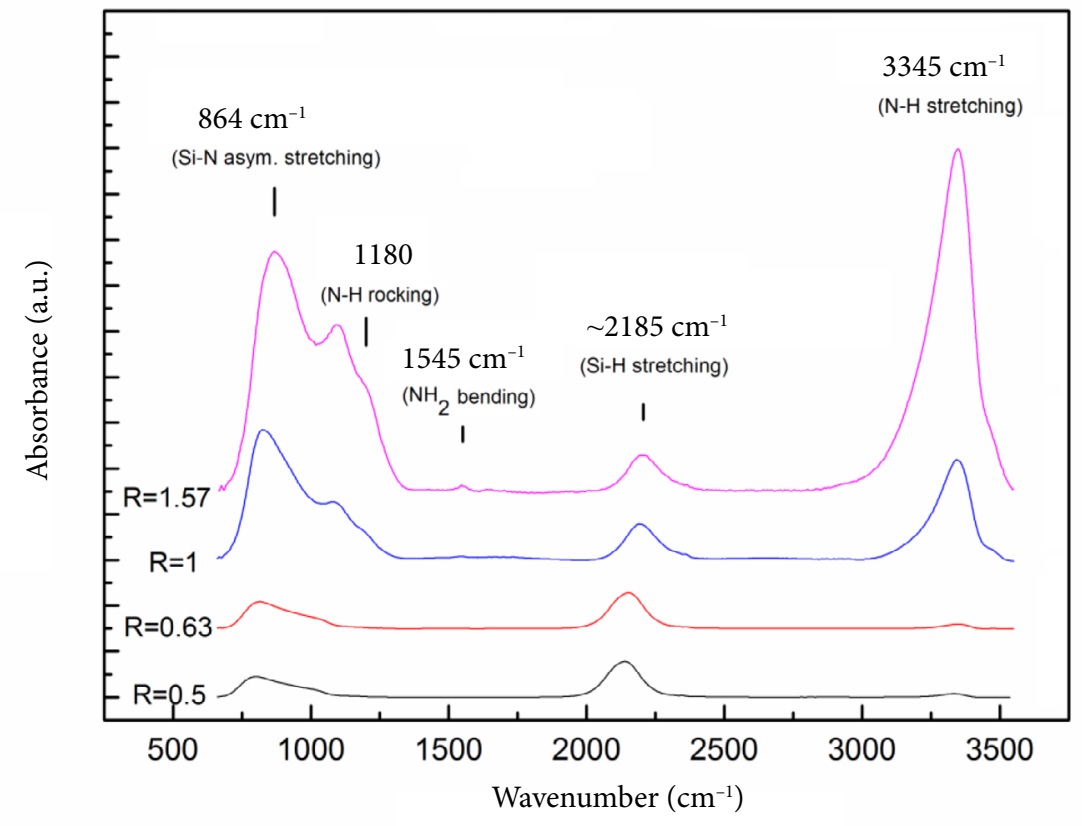

Fig. 6. FTIR spectra of $\mathrm{SiN}_{x}-\mathrm{III}$ samples grown at different gas ratios. 


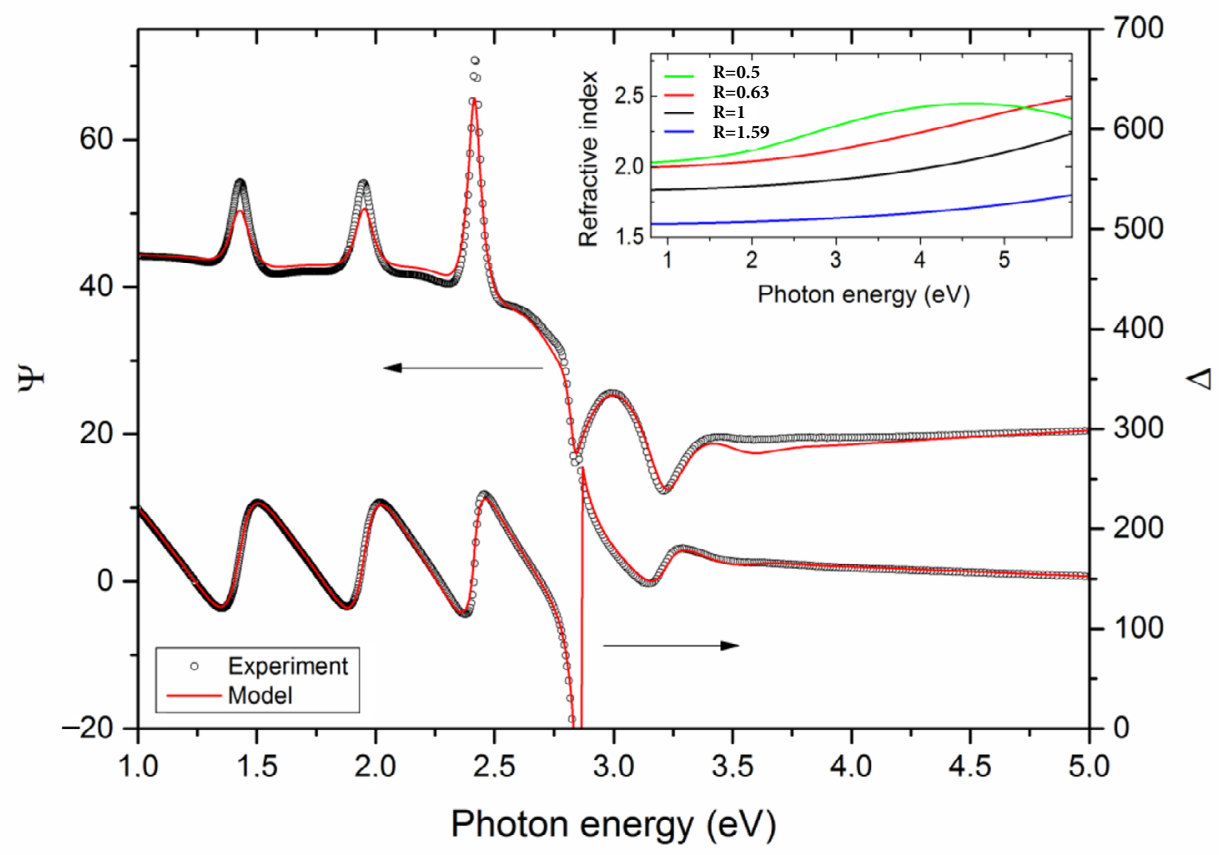

Fig. 7. Typical ellipsometric parameters $\Psi$ and $\Delta$ for the $\operatorname{SiN}_{x}$-III film. The fits obtained using the Tauc-Lorentz model are shown as lines. The insert shows the variation of refractive index of the $\mathrm{SiN}_{x}$-III samples grown at different gas ratios.

the three-phase model: Al covered glass substrate, $\mathrm{SiN}_{x}$ layer with surface roughness, and ambience. The best fit was achieved employing the Tauc-Lorentz model [22], which uses the Tauc expression (1) multiplied by the complex dielectric function of the Lorentz oscillator. The obtained refractive index of $\mathrm{SiN}_{x}$ varied in the range from 1.6 to 2.1 (at $632 \mathrm{~nm}$ ) depending on nitrogen concentration. The insert of Fig. 7 shows the refractive index of the $\mathrm{SiN}_{x}$-III series of samples as a function of wavelength. Silicon rich samples demonstrate higher values of the refractive index. This is a common pattern for silicon nitride. Stoichiometry of the film can be estimated from the refractive index $n$ according to [23]

$$
n=\frac{n_{\mathrm{a}-\mathrm{Si}}+\frac{3}{4} x\left(2 n_{\mathrm{Si}_{3} \mathrm{~N}_{4}}-n_{\mathrm{a}-\mathrm{Si}}\right)}{1+\frac{3}{4} x} .
$$

Here $n_{\mathrm{a}-\mathrm{Si}}$ and $n_{\mathrm{Si}_{3} \mathrm{~N}_{4}}$ are the refractive indexes of amorphous silicon and stoichiometric silicon nitride, respectively. For evaluation of the N/Si ratio the refractive indexes $n=3.4$ for amorphous silicon, as measured in the sample with $R=0$, and $n=1.9$ for nearly stoichiometric a- $\mathrm{Si}_{3} \mathrm{~N}_{4}$, as suggested in Ref. [24], have been used. Thus, N/Si ratio can be evaluated using the equation:

$$
x=\frac{\mathrm{N}}{\mathrm{Si}}=\frac{4}{3} \frac{3.4-n}{n-0.4} .
$$

The films deposited using the chemical vapour technique contain a significant amount of hydrogen [17, 25-26, but Eq. (7) neglects contribution from hydrogen bonding, resulting only in a rough estimation of stoichiometry [27]. Samuelson et al. [28] concluded that only the $\mathrm{N}-\mathrm{H} / \mathrm{Si}-\mathrm{H}$ bond ratio was directly correlated with the refractive index of $\mathrm{SiN}_{x}$, whereas the N/Si ratio does not have such simple correlation. In our research the N/Si ratio, estimated from Eq. (7), increases with increasing the gas ratio injected into the deposition system (Table 2).

\section{Conclusions}

Using a three-electrode and conventional two parallel-plate CVD chamber two series of $\mathrm{SiN}_{x}$ films were deposited. Although in the three-electrode reactor the layer deposition rates $(\sim 4.6 \mathrm{~nm} / \mathrm{min})$ were lower than the deposition rates in the parallel-plate reactor (up to $8.2 \mathrm{~nm} / \mathrm{min}$ ), however, lower deposition rate results in lower roughness of surfaces, together with lower leakage currents and higher breakdown voltages of the films. As expected, for both series of the samples the optical band gap increased with an amount of nitrogen in the layer. At the same $\mathrm{N}_{2} /\left(\mathrm{SiH}_{4}+\mathrm{Ar}\right)$ gas ratio, the stoichiometric index $x$ of the layers deposited in the three-electrode reactor was higher than that of the layers deposited by the two-electrode reactor. The highest content of nitrogen $(x=1.44)$ in the film with the widest band gap $(5.15 \mathrm{eV})$ was achieved in the three-electrode reactor.

\section{Acknowledgements}

The financial support from the Research Council of Lithuania through Project No. VP1-3.1-ŠMM07-K-01-023 is acknowledged. 


\section{References}

[1] V. Verlaan, C.H.M. van der Werf, Z.S. Houweling, I.G. Romijn, A.W. Weeber, H.F.W. Dekkers, H.D. Goldbach, and R.E.I. Schropp, Multicrystalline Si solar cells with very fast deposited (180 nm/min) passivating hot-wire CVD silicon nitride as antireflection coating, Prog. Photovolt. Res. Appl. 15(7), 563-573 (2007), http://dx.doi. org/10.1002/pip.760

[2] A.K. Sinha, H.J. Levinstein, T.E. Smith, G. Quintana, and S.E. Haszko, Reactive plasma deposited Si-N films for MOS-LSI passivation, J. Electrochem. Soc. 125(4), 601-608 (1978), http://dx.doi.org/10.1149/1.2131509

[3] L. Pavesi, Will silicon be the photonic material of the third millenium? J. Phys. Condens. Matter. 15, R1169-R1196 (2003), http://dx.doi. org/10.1088/0953-8984/15/26/201

[4] C.J. Oliphant, C.J. Arendse, T.F.G. Muller, and D. Knoesen, Characterization of silicon nitride thin films deposited by hot-wire CVD at low gas flow rates, Appl. Surf. Sci. 285, 440-449 (2013), http://dx.doi.org/10.1016/j.apsusc.2013.08.075

[5] M. Wang, X. Huang, J. Xu, W. Li, Z. Liu, and $\mathrm{K}$. Chen, Observation of the size-dependent blueshifted electroluminescence from nanocrystalline Si fabricated by $\mathrm{KrF}$ excimer laser annealing of hydrogenated amorphous silicon/amorphous$\mathrm{SiN}_{x}: \mathrm{H}$ superlattices, Appl. Phys. Lett. 72, 722-724 (1998), http://dx.doi.org/10.1063/1.120857

[6] R. Huang, H. Dong, D. Wang, K. Chen, H. Ding, X. Wang, W. Li, J. Xu, and Z. Ma, Role of barrier layers in electroluminescence from SiNbased multilayer light-emitting devices, Appl. Phys. Lett. 92, 181106 (2008), http://dx.doi. org/10.1063/1.2920819

[7] S. Okada and H. Matsumara, Improved properties of silicon nitride films prepared by the catalytic chemical vapour deposition method, Ipn. J. Appl. Phys. 36, 7035-7040 (1997), http://dx.doi. org/10.1143/JJAP.36.7035

[8] Q. Cheng, S. Xu, and K.K. Ostrikov, Controlledbandgap silicon nitride nanomaterials: deterministic nitrogenation in high-density plasmas, J. Mater. Chem. 20, 5853-5859 (2010), http:/ dx.doi.org/10.1039/C0JM01060J

[9] D. Drouin, A. Couture, D. Joly, X. Tastet, V. Aimez, and R. Gauvin, CASINO V2.42: a fast and easy-touse modeling tool for scanning electron microscopy and microanalysis users, Scanning 29, 92-101 (2007), http://dx.doi.org/10.1002/sca.20000

[10] J.C. Tauc, Optical Properties of Solids (North-Holland, Amsterdam, 1972).

[11] Q. Xu, Y. Ra, M. Bachman, and G.P. Li, Characterization of low-temperature silicon nitride films produced by inductively coupled plasma chemical vapour deposition, J. Vac. Sci.
Technol. A 145, 145-156 (2009), http://dx.doi. org/10.1116/1.3054133

[12] S.M. Sze, Physics of Semiconductor Devices (John Wiley \& Sons Inc., New York, 1969), http://dx.doi. org/10.1002/0470068329

[13] C. Kittel, Introduction to Solid State Physics, 8th ed., Ch. 7 (John Wiley \& Sons Inc., New York, 2005).

[14] E.H. Nicollian and J.R. Brews, MOS (Metal Oxide Semiconductor) Physics and Technology (Wiley, New York, 2002), http://dx.doi.org/10.1116/1.571867

[15] A. Piccirillo and A.L. Gobbi, Physical-electrical properties of silicon nitride deposited by PECVD on III-V semiconductors, J. Electrochem. Soc. 137, 3910-3917 (1990), http://dx.doi. org/10.1149/1.2086326

[16] P.R. Griffiths and J.A. de Haseth, Fourier Transform Infrared Spectrometry, 2nd ed. (John Wiley \& Sons Inc., New Jersey, 2007), http://dx.doi. org/10.1002/9780470106310.fmatter

[17] M.H. Brodsky, M. Cardona, and J.J. Cuomo, Infrared and Raman spectra of the silicon-hydrogen bonds in amorphous silicon prepared by glow discharge and sputtering, Phys. Rev. B 16, 3556-3571 (1977), http://dx.doi.org/10.1103/ PhysRevB.16.3556

[18] G. Lucovsky, J. Yang, S.S. Chao, J.E. Tyler, and W. Czubatyj, Nitrogen-bonding environments in glow-discharge-deposited a-Si:H films, Phys. Rev. B 28, 3234-3240 (1983), http://dx.doi.org/10.1103/ PhysRevB.28.3234

[19] D.V. Tsu, G. Lucovsky, and M.J. Mantini, Local atomic structure in thin films of silicon nitride and silicon diimide produced by remote plasmaenhanced chemical-vapor deposition, Phys. Rev. B 33, 7069-7076 (1986), http://dx.doi.org/10.1103/ PhysRevB.33.7069

[20] W.A. Lanford and M.J. Rand, The hydrogen content of plasma-deposited silicon nitride, I. Appl. Phys. 49(4), 2473-2477 (1978), http://dx.doi. org/10.1063/1.325095

[21] W.A.P. Claassen, W.G.J.N. Valkenburg, F.H.P.M. Habraken, and Y. Tamminga, Characterization of plasma silicon nitride layers, J. Electrochem. Soc. 130, 2419-2423 (1983), http://dx.doi. org/10.1149/1.2119600

[22] G.E. Jellison Jr., V.I. Merkulov, A.A. Puretzky, D.B. Geohegan, G. Eres, D.H. Lowndes, and J.B. Caughman, Characterization of thin-film amorphous semiconductors using spectroscopic ellipsometry, Thin Solid Films 377-378, 6873 (2000), http://dx.doi.org/10.1016/S00406090(00)01384-5

[23] E. Bustarret, M. Bensouda, M. Habrard, J. Bruyère, S. Poulin, and S. Gujrathi, Configurational statistics in $a$ - $\mathrm{Si}_{x} \mathrm{~N}_{y} \mathrm{H}_{z}$ alloys: A quantitative bonding analysis, Phys. Rev. B 38(12), 8171-8184 (1988), http://dx.doi.org/10.1103/PhysRevB.38.8171 
[24] J.J. Mei, H. Chen, and W.Z. Shen, Optical properties and local bonding configurations of hydrogenated amorphous silicon nitride thin films, L. Appl. Phys. 100(7), 073516 (2006), http://dx.doi. org/10.1063/1.2356915

[25] M. Wang, J. Huang, Z. Yuan, and A. Anopchenko, Light emission properties and mechanism of low-temperature prepared amorphous $\mathrm{SiN}_{x}$ films. II. Defect states electroluminescence, Appl. Phys. 104, 083505 (2008), http://dx.doi. org/10.1063/1.2996299

[26] B. Rezgui, A. Sibai, T. Nychyporuk, M. Lemiti, and G. Bremond, Effect of total pressure on the forma- tion and size evolution of silicon quantum dots in silicon nitride films, Appl. Phys. Lett. 96, 183105 (2010), http://dx.doi.org/10.1063/1.3427386

[27] G. Scardera, T. Puzzer, G. Conibeer, and M.A. Green, Fourier transform infrared spectroscopy of annealed silicon-rich silicon nitride thin films, J. Appl. Phys. 104, 104310 (2008), http://dx.doi. org/10.1063/1.3021158

[28] G.M. Samuelson and K.M. Mar, The correlations between physical and electrical properties of PECVD SiN with their composition ratios, J. Electrochem. Soc. 129, 1773-1778 (1982), http:// dx.doi.org/10.1149/1.2124291

\title{
TRIJŲ ELEKTRODŲ PE CVD KAMEROJE UŽAUGINTŲ SILICIO NITRIDO SLUOKSNIŲ TYRIMAS
}

\author{
T. Grigaitis ${ }^{\mathrm{a}}$, A. Naujokaitis ${ }^{\text {a }}$, S. Tumènas ${ }^{\mathrm{b}}$, G. Juška ${ }^{\text {a }}$, K. Arlauskas ${ }^{\mathrm{a}}$ \\ ${ }^{a}$ Vilniaus universiteto Kietojo kūno elektronikos katedra, Vilnius, Lietuva \\ ${ }^{\mathrm{b}}$ Fiziniu ir technologijos mokslu centro Optoelektronikos skyrius, Vilnius, Lietuva
}

\section{Santrauka}

Silano ir argono $\left(5 \% \mathrm{SiH}_{4}, 95 \%\right.$ Ar) dujų mišiniai bei azoto dujos buvo naudojami silicio nitrido sluoksnių gamybai dviejų ir trijų elektrodų cheminio garų nusodinimo (CVD) kamerose. Sluoksniai buvo formuojami tuo pačiu metu ant $\mathrm{CaF}_{2}$ kristalo ir aliuminiu padengto stiklinio padèklo, ikaitintu iki $300^{\circ} \mathrm{C}$. Keičiant injektuojamų dujų santyki silicio nitrido draustinés juostos tarpas kito nuo $1,85 \mathrm{eV}$ iki $5,15 \mathrm{eV}$. Atominès jègos mikroskopu nustatyta, kad trijuc elektrodų kameroje užaugintų bandinių paviršiaus nelygumas mažesnis. Elektriniai matavimai atskleidè, kad trijų elektrodų kameroje užauginti sluoksniai pasižymi mažesne nuotèkio srove ir aukštesne pramušimo itampa. Silicio nitrido sudètis buvo tiriama Rentgeno spindulių dispersijos (EDS) ir Furje spektrometrijos (FTIR) metodais. Naudojant elipsometrinę spektroskopinę analizę ir taikant Tauco-Lorenzo modeli ịvertinti sluoksnių lūžio rodikliai, kurie leido nustatyti silicio nitrido sluoksnio sudètị. 